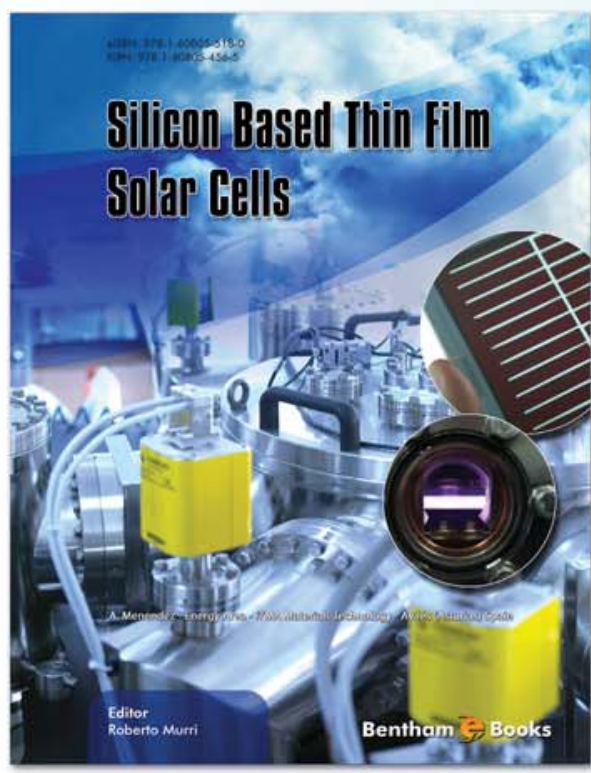

\title{
Editor:
}

Roberto Murri

Italy

eISBN: 978-1-60805-518-0

\section{Silicon Based Thin Film Solar Cells}

\section{Ww.henthamseience.com/ehooks/9781608055180}

\section{About the ebook}

Silicon Based Thin Film Solar Cells explains concepts related to technologies for silicon (Si) based photovoltaic applications. Topics in this book focus on 'new concept' solar cells. The textbook is a valuable resource for graduate students working on their theses, young researchers and all people approaching problems and fundamental aspects of advanced photovoltaic conversion.

\section{Contents}

Basics of Thin Film Solar Cells

Deposition of Thin Films: PECVD Process

Dputtering of Thin Films

- Molecular Beam Epitaxy (MBE)

- Infrared and Raman Spectroscopies

- Morphological and Structural Properties

- Optical Properties of Semiconductors

Electrical Properties of Semiconductors

\section{For Advertising Inquiries: Contact: marketing@benthamscience.org}

